\title{
Effect of glutaraldehyde biocide on laboratory-scale rotating biological contactors and biocide efficacy
}

\author{
Lakkana Laopaiboon* \\ Department of Biotechnology \\ Faculty of Technology and \\ Khon Kaen University \\ Khon Kaen 40002, Thailand \\ Tel/Fax: 6643362121 \\ E-mail: lakcha@kku.ac.th
Niphaphat Phukoetphim
Department of Biotechnology
Faculty of Technology
Khon Kaen University,
Khon Kaen 40002, Thailand
Tel/Fax: 6643362121
E-mail: aon201@hotmail.com

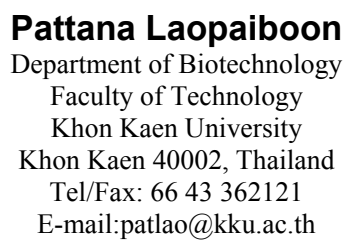

Research Center for Environmental Hazardous Substance Management

Financial support: Research Center for Environmental and Hazardous Substance Management, Khon Kaen University, Thailand and National Research Center for Environmental and Hazardous Waste Management, Chulalongkorn University, Thailand.

Keywords: acclimation, aldehyde biocide, biofilm, RBC, wastewater treatment.

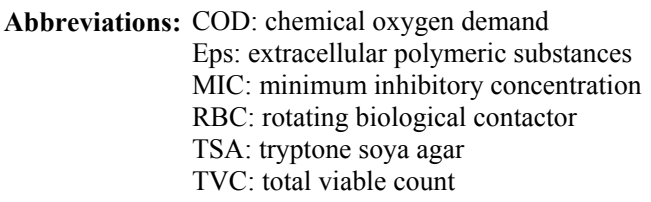

The effect of glutaraldehyde, a commercial biocide widely used in paper and pulp industry, on the performance of laboratory-scale rotating biological contactors (RBCs) as well as biocide efficacy was studied. Biofilms were established on the RBCs and then exposed to 0 - $180 \mathrm{ppm}$ glutaraldehyde at a dilution rate of $1.60 \mathrm{~h}^{-1}$. The results showed that the biofilms became acclimated to glutaraldehyde and eventually could degrade it. Acclimation to the biocide took longer at the higher biocide concentrations. The degree of biocide degradation and chemical oxygen demand (COD) removal depended on acclimation period, the presence of other organic matters and the amount of mineral salts available. Glutaraldehyde at up to $80 \mathrm{ppm}$ had no effect on treatment efficiency and populations of biofilms and planktonic phase of the system whereas glutaraldehyde at $180 \mathrm{ppm}$ caused a progressive decline in all measured values. However, no glutaraldehyde concentration used in the study was sufficiently high to kill microorganisms in the RBC system. The presence of biofilm provided additional resistance to glutaraldehyde to bacteria because the biocide had to penetrate through biofilm to reach bacteria. The increased resistance of bacteria to glutaraldehyde due to acclimation should be considered in biocide applications.

Glutaraldehyde (1,5-pentanedial) is a non-oxidizing biocide which achieves its biocidal activity by involving the crosslinking of the outer proteinaceous layers of the cell in such a way that cellular permeability is altered. The bacterial cell is unable to undertake most, if not all, of its essential functions. The ability of the outer covering of the cell to

*Corresponding author 
Table 1. Configuration of the single stage ( 3 disc) laboratory scale RBC unit.

\begin{tabular}{|c|c|}
\hline Features & Description \\
\hline \multicolumn{2}{|l|}{ Disc } \\
\hline Number & 3 discs \\
\hline Diameter & $267 \mathrm{~mm}$ \\
\hline Width & $3 \mathrm{~mm}$ \\
\hline Inter-disc spacing & $15 \mathrm{~mm}$ \\
\hline Material of manufacture & polyvinylchloride (PVC) \\
\hline Rotation speed (peripheral velocity) & $16 \mathrm{rpm}$ \\
\hline Disc submergence & $40 \%$ \\
\hline \multicolumn{2}{|l|}{ Drive shaft } \\
\hline Diameter & $25 \mathrm{~mm}$ \\
\hline Material of manufacture & stainless steel \\
\hline \multicolumn{2}{|l|}{ Tank } \\
\hline Diameter & $310 \mathrm{~mm}$ \\
\hline Wall thickness & $5 \mathrm{~mm}$ \\
\hline Material of manufacture & fiber glass \\
\hline \multicolumn{2}{|l|}{ Tank length } \\
\hline 1) Influent chamber & $65 \mathrm{~mm}$ \\
\hline 2) Disc chamber & $70 \mathrm{~mm}$ \\
\hline 3) Settling tank & $65 \mathrm{~mm}$ \\
\hline \multicolumn{2}{|c|}{ Operating conditions } \\
\hline \multicolumn{2}{|c|}{ Working volume* } \\
\hline 1) Influent chamber & $0.65 \mathrm{~L}$ \\
\hline 2) Disc chamber & $1.56 \mathrm{~L}$ \\
\hline 3) Settling tank & $1.55 \mathrm{~L}$ \\
\hline Flow rate of synthetic wastewater & $2.5 \mathrm{~L} \mathrm{~h}^{-1}$ \\
\hline Dilution rate & $1.60 \mathrm{~h}^{-1}$ \\
\hline Residence time in the disc stage & $37 \mathrm{~min}$ \\
\hline
\end{tabular}

${ }^{*}$ Corrected for the presence of discs, but not biofilms. 
transport nutrients to the cell and to remove waste products from the cell is hindered and cell death results (Russell and Chopra, 1996; Simons et al. 2000). Glutaraldehyde is widely used as an antimicrobial agent in a variety of applications such as in cooling water systems, paper-pulp industry, oilfield operation, leather tanning industry, poultry industry, cosmetic field, microbiological field, food industry and medical area. The extensive use of this biocide is due to being non-corrosive to stainless steel, soft metals, rubber and glass (Banner, 1995; Herbert, 1995; Lutey, 1995; Walsh et al. 1999).

Microbial biofilms play an essential role in engineered processes especially in biological treatment and energy production (Flemming, 1993; Bryers, 2000). They have been reported to have higher resistant to toxic compounds than free cell systems (Sofer et al. 1990; Lazarova and Manem, 2000). This makes them very useful in treating wastewaters containing toxic chemicals. However, suspended growth systems have the benefit of inherent dilution due to larger aeration volume as compared to attached-growth systems, which have known to be more susceptible to shock loadings.

Biofilms can cause many negative effects commonly termed biofouling in industrial water systems. Biofilm formation causes reductions in efficiency in industrial machinery, heat exchangers, vessels and filters (Melo and Bott, 1997; Bott, 1998; Das et al. 1998) and may cause acceleration of metallic corrosion (Cloete et al. 1998). Numerous methods have been used for minimizing adverse effects of biofilm formation. The most widely practiced approach to control biofouling is by way of chemical treatment using biocides (Cheung and Beech, 1996; Stewart et al. 2000).
The widespread application of biocides in many industries to control growth of planktonic and / or sessile microorganisms in a biofilm can cause environmental and ecological problems because sooner or later the biocides will have to be discharged into the environment either natural water or municipal effluent treatment plants (Nishiyama et al. 1995; Wyndham and Kennedy, 1995; Johnston et al. 1998; Reuter, 1998; Bailey et al. 1999; Sarlin et al. 1999; Juergensen et al. 2000; Nishihara et al. 2000). Therefore, knowledge of the effects of biocides on wastewater treatment units and their efficacy against bacterial cells is important.

Rotating biological contactors (RBCs) are one of the standard methods of biological wastewater treatment in which degradation and bio-oxidation are predominantly achieved by a biofilm which is attached to the rotating discs (Arundel, 1995; Banerjee, 1997; Casey, 1997). The RBC process is recommended for wastewater treatment because of simplicity in construction and maintenance, stable operation and relatively low cost. Laboratory-scale RBC units may be used to predict the effect of the biocide on the operation of full scale RBC, the ability of full scale RBCs to degrade biocides and the ability of biocides to control and eliminate biofilms in continuous systems.

In this study the effects of $50 \%$ glutaraldehyde, a commercial biocide widely used in paper and pulp industry, on biofilms in RBCs and on biofilm establishment in RBCs after acclimation have been investigated. The effects of the biocide on the reduction in chemical oxygen demand (COD) and glutaraldehyde concentration of the synthetic wastewater applied to the RBCs were determined. The development of resistant / acclimatized microflora to the biocide and the effects that such microorganisms would have on biocide degradation as a sole carbon source and

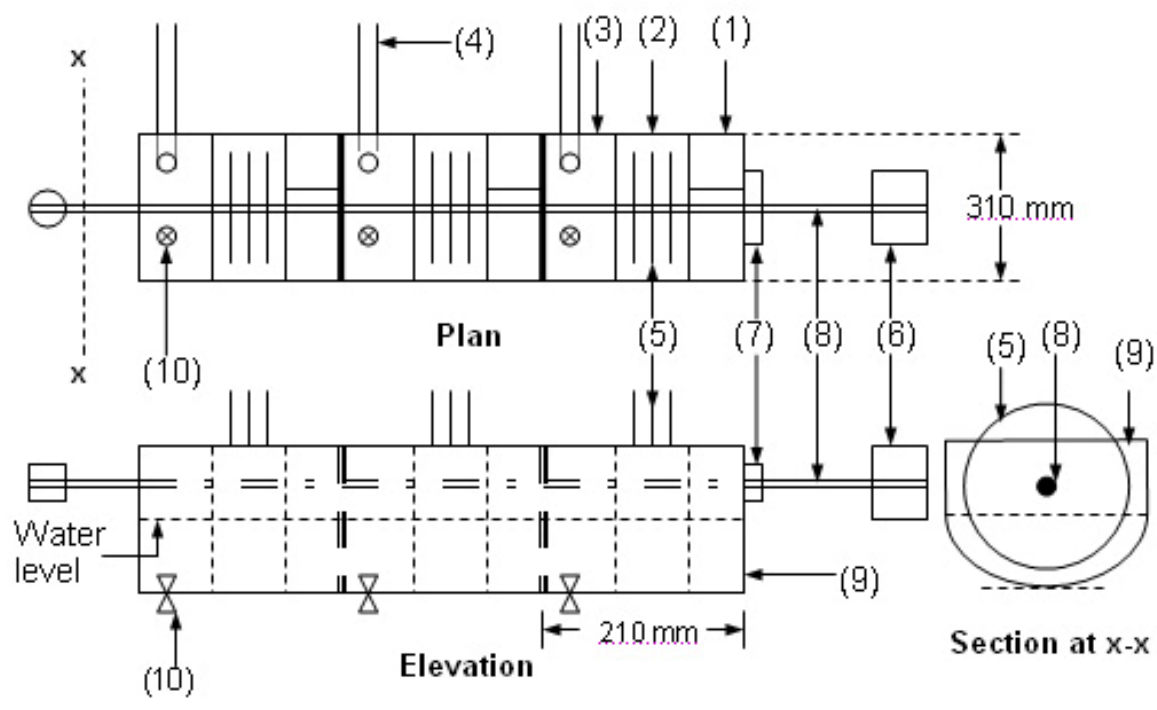

Figure 1. The single-stage ( 3 disc) laboratory scale RBC units. 1: influent chamber; 2 : disc stage; 3 : settling tank; 4: overflow tube; 5: RBC disc; 6: motor; 7: bearing; 8: shaft; 9: tank; 10: gate valve. 
Table 2. Effect of glutaraldehyde on chemical oxygen demand removal at steady state.

\begin{tabular}{|c|c|c|c|c|}
\hline \multirow{2}{*}{$\begin{array}{c}\text { Glutaraldehyde } \\
\text { concentration (ppm) }\end{array}$} & \multicolumn{2}{|c|}{ COD (mg L $\left.{ }^{-1}\right)$} & \multicolumn{2}{c|}{ COD removal } \\
\cline { 2 - 5 } & Influent & Effluent & mg L $^{-1}$ & Percentage \\
\hline 0 & $106.33 \pm 4.96$ & $30.67 \pm 9.62$ & $74.00 \pm 7.24$ & $71.73 \pm 7.67$ \\
\hline 40 & $153.33 \pm 10.01$ & $65.00 \pm 2.00$ & $86.67 \pm 6.11$ & $57.47 \pm 1.75$ \\
\hline 80 & $292.00 \pm 12.00$ & $140.00 \pm 13.06$ & $158.00 \pm 10.07$ & $53.05 \pm 3.55$ \\
\hline 180 & $427.43 \pm 36.03$ & $280.00 \pm 22.63$ & $93.33 \pm 20.13$ & $39.72 \pm 3.10$ \\
\hline
\end{tabular}

RBC treatment efficiency were observed. Differences in susceptibility of planktonic and biofilm bacteria to glutaraldehyde were also compared.

\section{MATERIALS AND METHODS}

\section{The single-stage (three-disc) laboratory-scale rotating biological contactor units}

Single-stage laboratory-scale RBC units were constructed in groups of three, the three units being served by a common motor and drive shaft (Figure 1). Each unit consisted of an influent chamber, a disc chamber and an inbuilt settling tank. These compartments were separated by PVC walls, each containing a 20-mm diameter transfer hole near the base of the wall through which liquor and suspended biomass passed. In each unit the treated liquor from the disc chamber was passed to the settling tank, where the biomass was removed, before being discharged via an overflow tube. Settled biomass was removed from each settling tank via a low-level gate valve. The configuration of the single stage laboratory scale RBC units is shown in Table 1.

\section{The synthetic wastewater}

The standard synthetic wastewater consisted of lab-lemco broth, $90 \mathrm{mg} \mathrm{L}^{-1}$ which composed of $33.75 \mathrm{mg} \mathrm{L}^{-1}$ lablemco powder (Oxoid) and $56.25 \mathrm{mg} \mathrm{L}^{-1}$ bacteriological peptone (Oxoid); $\mathrm{NH}_{4} \mathrm{Cl}, 54 \mathrm{mg} \mathrm{L}{ }^{-1} ; \mathrm{K}_{2} \mathrm{HPO}_{4}, 28 \mathrm{mg} \mathrm{L}^{-1}$; $\mathrm{NaCl}, 7 \mathrm{mg} \mathrm{L}^{-1} ; \mathrm{CaCl}_{2} \cdot 2 \mathrm{H}_{2} \mathrm{O}, 4 \mathrm{mg} \mathrm{L}{ }^{-1}$ and $\mathrm{MgSO}_{4} \cdot 7 \mathrm{H}_{2} \mathrm{O}, 2$ $\mathrm{mg} \mathrm{L}^{-1}$ (modified from Laopaiboon et al. 2002).

\section{Establishment biofilms and biocide treatments}

An inoculum of recycled sludge (0.5 litres) from the wastewater treatment system of Phoenix Pulp and Paper Public Company Ltd., Khon Kaen, Thailand, was added into the disc stage of the RBC units filled with the synthetic wastewater. The units were operated as a batch system for $24 \mathrm{hrs}$ before the flow of the synthetic wastewater was introduced to the units at a rate of $2.5 \mathrm{~L} \mathrm{~h}^{-1}$. Approximately two weeks the surface of the discs was covered by a thin homogeneous biofilm about 1-2 mm thick. A commercial biocide, glutaraldehyde $50 \%$ aqueous solution (Ondeo Nalco, Thailand) was then added to the synthetic wastewater to give final concentrations of $0,40,80$ and 180 ppm (active ingredients).

\section{Minimum inhibitory concentration (MIC) of glutaraldehyde}

MIC of glutaraldehyde on three types of inoculum was determined. The three inocula were 'TSA cells' (planktonic cells from the disc stage of the control RBC inoculated onto TSA slant at $37^{\circ} \mathrm{C}$ for $24 \mathrm{hrs}$ ), 'control planktonic cells' (planktonic cells from the disc stage of the control RBC) and 'acclimatized cells' (planktonic cells from the disc stage at steady state of the experiment in next section). The MIC was determined by inoculating one $\mathrm{ml}$ of the inoculum into a series of sterile vials containing $9 \mathrm{ml}$ of the synthetic wastewater and the desired concentration of glutaraldehyde. The vials were incubated at $37^{\circ} \mathrm{C}$ for $48 \mathrm{hrs}$. The lowest concentration of bactericide showing absence of growth by total viable count (TVC) measurement was taken to be MIC.

Capability of microorganisms to re-establish an active biofilm in the presence of glutaraldehyde as a sole carbon source and tentative identification of resistant microorganisms

The planktonic microorganisms ( 0.5 litres) which had previously been subjected to glutaraldehyde at $180 \mathrm{ppm}$ for 18 days were added to the disc stage of the two clean RBC units filled with the synthetic wastewater containing 180 ppm glutaraldehyde. The units were operated as a batch system for $24 \mathrm{hrs}$ before the flow of the wastewater A (the wastewater containing the mineral salts and $180 \mathrm{ppm}$ glutaraldehyde) or the wastewater B (the wastewater containing only $180 \mathrm{ppm}$ glutaraldehyde) was introduced to the units at a rate of $2.5 \mathrm{~L} \mathrm{~h}^{-1}$. Biofilm formation on the $\mathrm{RBC}$ discs was then observed. If a biofilm was able to reestablish, all measurements as described below were performed. At the end of the experiment, single colonies of 


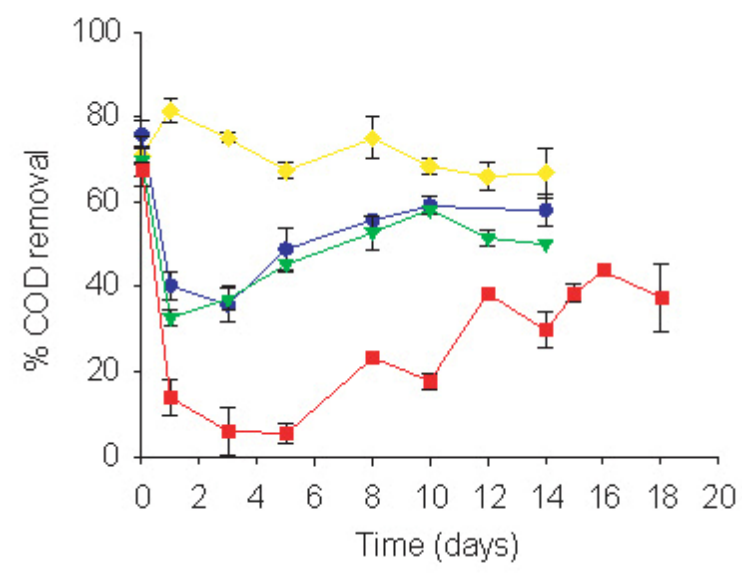

Figure 2. Effect of glutaraldehyde on chemical oxygen demand (COD) removal in the rotating biological contactors. Control ( ); $40 \mathrm{ppm}(\bullet)$; $80 \mathrm{ppm}(\nabla)$; and $180 \mathrm{ppm}$ $(\square)$.

bacterial cells in the biofilms were isolated on tryptone soya agar (TSA) plate by spread plate technique. The colonies were tentatively identified by the API 20 NE strip test (BioMérieux SA, France).

\section{Sampling and analysis}

Chemical oxygen demand and glutaraldehyde concentration. Influent and effluent samples were filtered through a $47 \mathrm{~mm}$ diameter, $0.2 \mu \mathrm{m}$ pore size, cellulose acetate membrane filter (Whatman) to remove bacterial cells. The COD of the samples was then determined by the modified closed reflux, titrimetric method (APHA AWWA and WPCE, 1995). Standard ferrous ammonium sulphate, $0.025 \mathrm{M}$, was used as a titrant. Glutaraldehyde concentrations were measured by colorimetric micromethod (Boratynski and Zal, 1990).

Enumeration of viable populations of biofilm and planktonic bacteria. A one- $\mathrm{cm}^{2}$ disc was cut from the biofilm using a sharp, sterilized cork borer $(1.13 \mathrm{~cm}$ diameter). The biofilm was removed using a sterile scalpel and placed in $9 \mathrm{ml}$ quarter strength Ringer's solution. The sample was sonicated for $5 \mathrm{~min} 3$ times and vortex mixed between sonication for $10 \mathrm{sec}$ (Stoodley et al. 1999) and a (TVC) was then performed. The liquid in the disc chamber was also sampled and the TVC of the planktonic organisms was determined. TSA was employed for all TVC's throughout the experiments and all plates were incubated at $37^{\circ} \mathrm{C}$ for $48 \mathrm{hrs}$.

Population changes of higher organisms in the biofilm. Samples of the biofilm were mounted on a microscope slide. Population changes of protozoa and mesozoan in the samples were observed by visual microscopy at magnification of (x 400).

\section{RESULTS AND DISCUSSION}

\section{Biofilm formation}

The single-stage laboratory-scale RBCs proved to be a very efficient system to establish a biofilm under the operating conditions used. Twenty four hours as a batch system at the beginning of the operation was sufficient for the induction phase of biofilm formation-organic absorption following by the transport and subsequent attachment of microorganisms to the surface (Trulear and Characklis, 1982). Some biofilms detached from the discs and re-established onto the $\mathrm{RBC}$ discs resulting in relatively stable biofilm thickness in all treatments. The results obtained also suggest that the polyvinylchloride is a good material for supporting good growth of a mixed population biofilm. This was supported by Apilánez et al. (1998) and Kerr et al. (1999) who found that the rate of biofilm formation and total viable population of biofilm depend on substratum.

The biofilms on the discs of the treated RBC units with glutaraldehyde were markedly thicker than those of the control RBC unit. They appeared to be composed of the large amounts of slime. The increased biofilm thickness without any increase in the treatment efficiency of the system can be explained by Venkataraman and Ramanujam (1998) who reported that the substrate removal rate depends on the active outer layer of biofilm and the depth of active layer being controlled by the diffusivity of dissolved oxygen into the biofilm. The results obtained in this study were agreed with Laopaiboon et al. (2001) who found that the increased age of biofilm and consequently the increased thickness did not result in significantly higher treatment efficiency of a wastewater treatment system. The increase in the thickness was probably due to cross-linking between glutaraldehyde and the amine group of proteins or enzymes found on bacterial cell walls (Simons et al. 2000). Moreover, glutaraldehyde may also react with protein which is the one of the predominant constituents of biofilm extracellular polymeric substances (EPS) apart from polysaccharide (Christensen and Characklis, 1990; Flemming, 1993; Norwood and Gilmour, 2000).

\section{Treatment efficiency of the RBCs}

Figure 2 shows that COD removal of the control unit (without glutaraldehyde) was $71.73 \pm$ S.D. 7.67\%. When 40 and 80 ppm glutaraldehyde were applied to the units, COD removal decreased to around $34-40 \%$ on day 1 but then subsequently recovered and reached steady state on day 810 with average COD removals of $57.47 \pm 1.75$ and $53.05 \pm$ $3.55 \%$ respectively. Applying at $180 \mathrm{ppm}$, glutaraldehyde caused increasing reductions in COD removal with almost total inhibition occurring on day 5 of the treatment but then slightly increased to $39.72 \pm 3.10 \%$ on day $12-18$. As one ppm glutaraldehyde equates $2 \mathrm{mg} \mathrm{L}^{-1} \mathrm{COD}$, the COD of each influent wastewater containing glutaraldehyde will be increased by the presence of glutaraldehyde as shown in Table 2. 
Table 3. Higher organisms in the biofilms on the RBC discs at the end of the experiments.

\begin{tabular}{|c|c|c|c|c|}
\hline \multirow{2}{*}{ Organisms } & \multicolumn{4}{|c|}{ Glutaraldehyde concentration (ppm) } \\
\hline & 0 (Control) & 40 & 80 & 180 \\
\hline Protozoa & +++ & ++ & ++ & - \\
\hline Rotifer & ++ & + & + & - \\
\hline
\end{tabular}

Figure 3 indicates that when glutaraldehyde was applied to the RBCs at 40 and $80 \mathrm{ppm}$, the biocide was almost totally removed by the units since day 3 and day 8 respectively. The average concentrations of glutaraldehyde remaining in the effluents were only $5.29 \pm 1.64$ and $6.14 \pm 1.44 \mathrm{ppm}$, respectively. At $180 \mathrm{ppm}$ glutaraldehyde, the biocide content of the effluent was decreased at approximately 40 ppm between day 1 and day 5 but then subsequently decreased with glutaraldehyde concentration showing only $58.99 \pm 4.11 \mathrm{ppm}$ at the end of the experiment.

Glutaraldehyde at concentrations of up to $80 \mathrm{ppm}$ did not significantly affect the consumption of lab-lemco broth (sole carbon source in the synthetic wastewater) by the mixed populations in the RBCs. COD removal in the untreated control $\mathrm{RBC}$ was around $74 \mathrm{mg} \mathrm{L}^{-1}$ while at 40 and $80 \mathrm{ppm}$ glutaraldehyde COD removal increased to 87 and $158 \mathrm{mg} \mathrm{L}^{-1}$, respectively (Table 2). The increase in COD removed at 40 and 80 ppm glutaraldehyde treatments $\left(87-74=13 \mathrm{mg} \mathrm{L}^{-1}\right.$ and $158-74=84 \mathrm{mg} \mathrm{L}^{-1}$, respectively) suggested that not only lab-lemco broth but also glutaraldehyde were removed by the RBC units. At

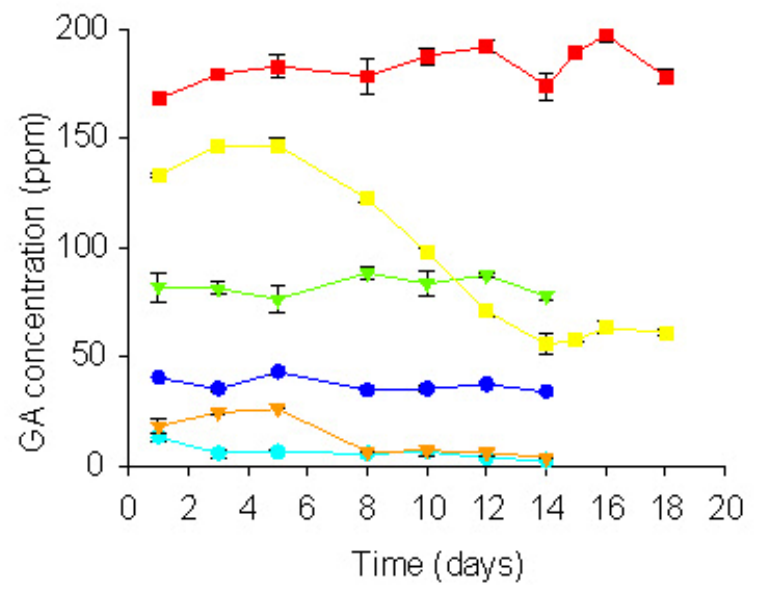

Figure 3. Glutaraldehyde (GA) removal in the rotating biological contactors. influent $40 \mathrm{ppm}(\bullet)$, effluent $40 \mathrm{ppm}(\bullet)$, influent $80 \mathrm{ppm}(\nabla)$, effluent $80 \mathrm{ppm}(\nabla)$, influent $180 \mathrm{ppm}(\boldsymbol{\square})$ and effluent $180 \mathrm{ppm}()^{)}$.
180 ppm glutaraldehyde treatment, the increase in COD removed $\left(93-74=19 \mathrm{mg} \mathrm{L}^{-1}\right)$ and glutaraldehyde removed $(180-59=121 \mathrm{ppm})$ indicated that the COD removed at this concentration was probably mainly derived from glutaraldehyde and not from lab-lemco broth. This implies that applying high biocide concentration to a wastewater treatment plant may inhibit simple carbon source utilization by microorganisms in the system.

\section{Biocide efficacy on populations in the RBC system}

Biofilm and planktonic populations. The colony forming measurement was chosen to assess biocide efficacy on microbial activity as it was an economical method. Figure 4 shows that glutaraldehyde had no adverse effect on the viability of the biofilms and apparent planktonic bacteria in the RBCs at concentrations of up to $80 \mathrm{ppm}$ even though the thickness of the treated biofilms was greater than that of the control biofilms. The TVCs of the biofilms on the discs were similar at approximately $10^{7}-10^{8} \mathrm{cfu} \mathrm{cm}^{-2}$. This implies that the biofilm thickness does not have a marked effect on the levels of efficacy of the biocide tested. Russell and Chopra (1996) reported that viability of microorganisms is not always affected when exposed to a biocide that interacts with an outer cellular component such as glutaraldehyde.

Our previous study found that the maximum specific growth rate of the planktonic cells in the synthetic wastewater in a batch system was $0.84 \mathrm{~h}^{-1}$ (Phukoetphim et al. 2004). This was far lower than the dilution rate $\left(1.60 \mathrm{~h}^{-1}\right)$ in the disc chamber of the three-disc RBC operation, however, no washout of the planktonic phase in the disc chamber was observed. This indicates that the apparent planktonic population of the RBCs at all treatments including the control treatment, must be continually replenished by organisms detaching from the biofilm which serves as a continuous source of bacteria for the liquid phase (Characklis and Marshall, 1990). The TVCs of planktonic microorganisms in the $\mathrm{RBC}$ receiving glutaraldehyde at concentrations of up to $80 \mathrm{ppm}$ were similar indicating that the number of bacteria released from the biofilms remained unchanged. Reduction in numbers of 
Table 4. MIC of glutaraldehyde on planktonic microorganisms.

\begin{tabular}{|c|c|}
\hline Inoculum & MIC (ppm) \\
\hline TSA cells & 25 \\
\hline control planktonic cells & 30 \\
\hline acclimatized cells & $40-50$ \\
\hline
\end{tabular}

cfu's at higher glutaraldehyde concentration may be due to reduced growth rate or the death of some cells in the biofilms. Bacterial cfu's of the biofilm exposed to $180 \mathrm{ppm}$ was one $\log$ reduction, implying that the growth was reduced or inhibited and consequently fewer planktonic microorganisms being detected in the disc stage. However, cfu's at $180 \mathrm{ppm}$ recovered nearly to the control level following acclimation.

Higher organisms. Microscopic observation shows that higher organisms in the biofilms of all RBC units before the biocide treatments consisted of active protozoa and rotifers. Glutaraldehyde at concentrations of up to $80 \mathrm{ppm}$ caused slight changes in population of protozoa (Table 3). All higher organisms were killed in the biofilms exposed to 180 ppm glutaraldehyde since day 1 of the experiments indicating that protozoa and rotifers were more sensitive to glutaraldehyde than bacterial cells in the biofilms.

\section{Susceptibility changes of cells to the bactericidal activity following acclimation and protective action of the biofilms}

The susceptibility of cells to the bactericidal activity of glutaraldehyde can be assessed by determination of MIC. Table 4 shows that MICs of glutaraldehyde on 'TSA cells' and 'control planktonic cells' were similar at $25-30 \mathrm{ppm}$. Resistance of cells to glutaraldehyde was found in 'acclimatized cells' resulting in higher MIC value.

The results indicate that there was no difference in susceptibility to glutaraldehyde on cells grown in enriched medium (TSA) and the cells sloughed from biofilms which were not subjected to the biocide application. It is accepted that sessile bacteria are more resistant to a biocide than their planktonic counterparts (Eginton et al. 1998; Stewart et al. 1998; Laopaiboon et al. 2002). However, when the bacteria in the biofilms shed to the planktonic phase, they showed no increase in resistance to the biocide. After a period of acclimation, planktonic cells sloughed from the acclimatized biofilms showed significantly less susceptibility to the biocide with higher MIC when compared to those of the unacclimatized biofilms. The results also showed that the susceptibility of cells possibly related to capability of biocide degradation. Biodegradation of the acclimatized cells at $180 \mathrm{ppm}$ glutaraldehyde for 2 weeks was far higher than that of the biofilms exposed to the biocide for a shorter period.

The results clearly show that biocide efficacy on bacterial cells in biofilms and their planktonic counterparts are significantly different. The bacteria within biofilms are more resistant to the biocide than their planktonic cells. In planktonic cells biooxidation was totally inhibited in the presence of $25 \mathrm{ppm}$ glutaraldehyde while biofilms retained some of their bio-oxidation capacity in the presence of glutaraldehyde up to $180 \mathrm{ppm}$. This may be attributed to the effect of exopolysaccharide polymers produced as a potential barrier which can prevent biocides from reaching the target organisms within the biofilms (Das et al. 1998; Morton et al. 1998; Stewart et al.1998). It can be assumed that in the presence of biocide planktonic bacteria play no part in the substrate removal and only bio-oxidation by the biofilms takes place. The results of this study indicate that there is at least a seven-fold difference in susceptibility of planktonic and biofilm cells to glutaraldehyde.
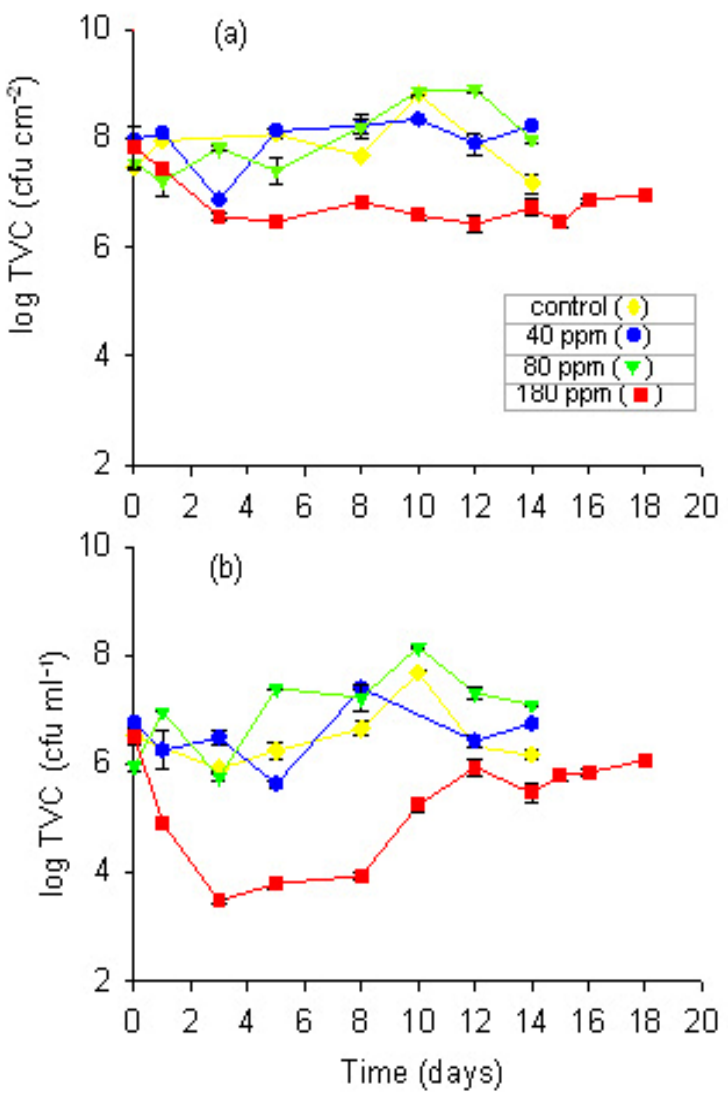

Figure 4. Effect of glutaraldehyde on cell viability in the rotating biological contactors.

(a) Biofilms.

(b) Apparent planktonic cells. 


\section{Re-establishment an active biofilm, biodegradation of biocide and its removal as a sole carbon source by resistant cells}

The capability of the acclimatized cells to form a biofilm on the discs was investigated to simulate biofilm formation in a water system under sub-inhibitory concentrations and to study the biocide efficacy against microbial cells under these conditions. In the RBCs receiving the wastewater A and $\mathrm{B}$ containing $180 \mathrm{ppm}$ glutaraldehyde as a sole carbon source, biofilm formation was noticed on day 3 of the experiments. This was slightly longer than in the control unit (no biocide) where the biofilm established in 2 days. The results may reflect the fact that the microorganisms were slower growing in the presence of biocide and a longer period of time was necessary for surface coverage to be achieved.

Figure $5 \mathrm{a}$ and $5 \mathrm{~b}$ show that the degree of COD removal and biocide degradation depends on acclimation period, the presence of other organic matters and the amount of mineral salts available. COD and glutaraldehyde removals in the units receiving the wastewater A and B were initially quite low. After a period of acclimation for approximately 10 days, the biofilms could degrade glutaraldehyde. Glutaraldehyde removal had subsequently increased and reached steady state on day 28 . The average glutaraldehyde removals were $71.36 \pm 1.99$ and $20.67 \pm 1.94 \%$ by the RBCs receiving the wastewater $\mathrm{A}$ and $\mathrm{B}$ respectively (Figure 5b). Similar results were observed by COD measurement (Figure 5a). COD removal reached constant level approximately on day 18 with average COD removal of $38.84 \pm 2.93$ and $19.97 \pm 1.78 \%$ by the RBCs receiving the wastewater A and B respectively. The viable populations of the biofilms and the planktonic cells in the $\mathrm{RBCs}$ receiving the wastewater $\mathrm{A}$ were higher than those of the $\mathrm{RBC}$ receiving the wastewater $\mathrm{B}$ around 1.3 and $1.7 \mathrm{log}$ scales respectively (Table 5). However, those values were still lower when compared with those of the RBC receiving normal synthetic wastewater without glutaraldehyde.

In the absence of additional mineral salts in the influent, the percentage of glutaraldehyde and COD removals was similar at approximately $20 \%$. This indicates that ultimate biodegradation of biocide had occurred. On the other hand, in the presence of additional mineral salts, the percentage of glutaraldehyde removal was significantly higher than that of COD removal. A possible explanation was that the biocide may not be completely degraded to $\mathrm{CO}_{2}$ (mineralization) but it was converted to intermediates or combined with other components in the wastewater which could not be detected by glutaraldehyde determination but were detected as COD. However, more glutaraldehyde could have been removed if the RBC system was operated longer and/or COD loading was lower. The effect of operating conditions of the RBC performance on glutaraldehyde degradation is being investigated by the authors.

The results obtained indicate that glutaraldehyde biocide could still be removed regardless the presence of simple carbon sources. However, some biocides such as isothiazolone compounds could only be degraded via cometabolism with a growth substrate or readily degradable carbon source (Laopaiboon et al. 2001).

Our previous study showed that the loss of glutaraldehyde in the RBC unit without biofilms and any reaction between the biocide and normal synthetic wastewater was minimal (Phukoetphim et al. 2004). Thus the removal of glutaraldehyde could be attributed to biological action or biodegradation. As previously mentioned, biofilms played an important role in biodegradation of the biocide because the MIC of their planktonic counterparts was much lower than the biocide concentrations applied to the RBCs.

Van Ginkel (1991) and Cornelissen and Sijm (1996) reported that the difference in degree of biodegradation of certain chemicals depends on the structure of the substance, the concentration of the chemical, environmental conditions such as temperature, oxygen levels and $\mathrm{pH}$ and the presence of other nutrients. In this study, $\mathrm{pH}$ and temperature of the wastewater in the $\mathrm{RBC}$ system ranged from 7.12 to 7.36 and 24.5 to $27.5^{\circ} \mathrm{C}$, respectively indicating that these conditions were suitable for glutaraldehyde degradation. However, dissolved oxygen concentration in the RBC system should also be monitored to show whether there was any impact of the loading increase on DO concentration or

Table 5. Viability of re-established biofilms of the RBCs receiving the wastewater A and B and untreated biofilms of the control RBC.

\begin{tabular}{|c|c|c|c|}
\hline Viability & Control RBC & $\begin{array}{c}\text { RBC receiving } \\
\text { wastewater A }\end{array}$ & $\begin{array}{c}\text { RBC receiving } \\
\text { wastewater B }\end{array}$ \\
\hline TVC of biofilms $\left(\log \mathrm{cfu} \mathrm{cm}^{-2}\right)$ & $7.89 \pm 0.52$ & $6.39 \pm 0.39$ & $5.11 \pm 0.55$ \\
\hline TVC of planktonic cells $\left(\log \mathrm{cfu} \mathrm{ml}^{-1}\right)$ & $6.57 \pm 0.57$ & $5.90 \pm 0.42$ & $4.19 \pm 0.46$ \\
\hline
\end{tabular}

Wastewater $\mathrm{A}=$ the wastewater containing the mineral salts and $180 \mathrm{ppm}$ glutaraldehyde.

Wastewater $\mathrm{B}=$ the wastewater containing only $180 \mathrm{ppm}$ glutaraldehyde.

${ }^{*}$ The results are expressed as mean and standard deviation during steady state. 
oxygen supply was sufficient to meet the increase in COD loading.

Less diversity of biofilm bacteria was observed in the RBCs receiving biocide-based wastewater. Bacterial cells from the biofilms were isolated at the end of the experiments. All tested isolates were Gram-negative rods and oxidase positive. The resistant bacterium to glutaraldehyde was tentatively identified as predominantly of the species Burkholderia cepacia. Other resistant species found were Aeromonas hydrophila and Aeromonas salmonicida. The results were similar to Bae and Rittmann (1995) who found that the dominant species in continuousflow reactor of mixed phenolic compounds were Burkhol. cepacia and Pseudomonas testosteroni. Nikaido (1994) also reported that Pseudomonas and Burkholderia are highly resistant to most of the commonly used antimicrobial agents. Intrinsic resistance mechanisms, such as differences in their outer membrane permeability and the efficiency of their active efflux pumps, are thought to be responsible. In metalworking fluids, however, Gram-positive bacteria, mycobacteria, were found to be more resistant to biocides
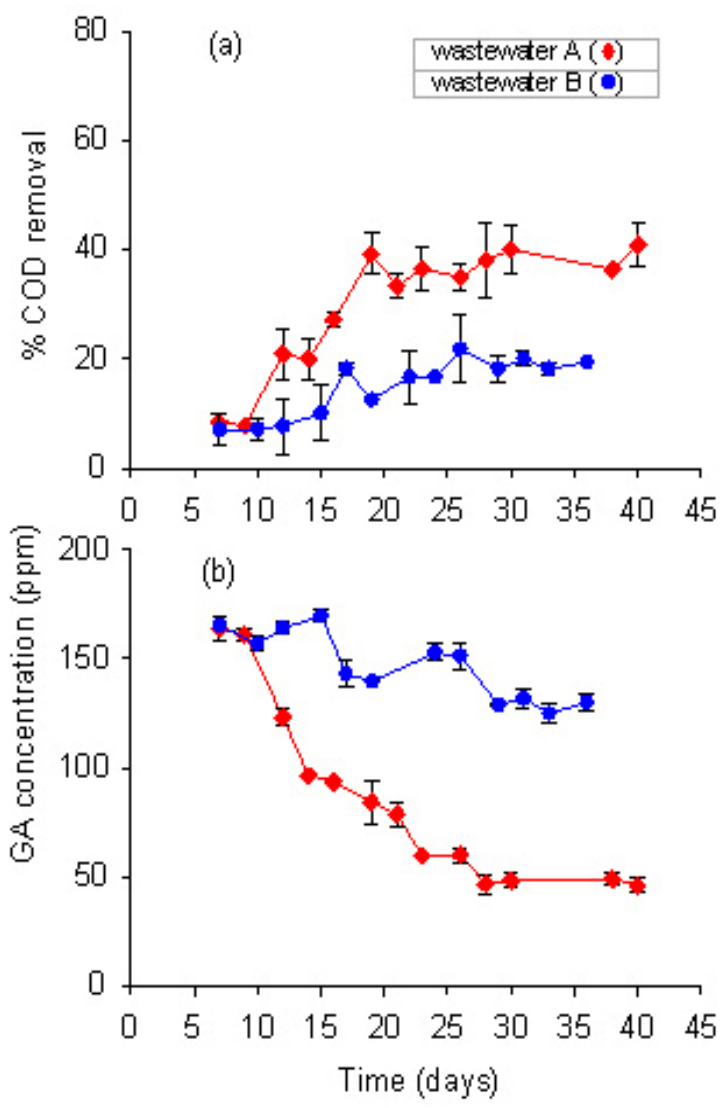

Figure 5. Treatment efficiency of the rotating biological contactors receiving wastewater $A$ and wastewater $B$ containing $180 \mathrm{ppm}$ glutaraldehyde during reestablishment biofilms of acclimatized cells.

(a) Chemical oxygen demand removal.

(b) Glutaraldehyde (GA) removal. than Gram-negative bacteria, pseudomonads (Russell, 1998; Selvaraju et al. 2005).

\section{Industrial biocide application}

The quantity of biocides applied in, for example, cooling systems is generally calculated from MIC determined under laboratory conditions (Lutey, 1995). Due to the high cost of the volumes of biocide required and their environmental impact, addition of biocide is kept to minimum. A certain MIC of a biocide is required to maintain control over the microbial community in a system. However, in practice the active concentrations of most biocides in systems drop after addition due to a number of factors. Many biocides react with constituents of the system being treated, e.g. proteins, polysaccharides of the biofilm matrix, metal surfaces or with cells, resulting in depletion of the available biocide pool. As a result the available concentration of biocide in the system being treated is lower than required most of the time and therefore, the bacterial communities are exposed to sub-inhibitory concentrations of biocides (Brözel et al. 1995; Cloete et al. 1998). Moreover, the results indicate that susceptibility of bacteria to a biocide is reduced after a period of acclimation especially when there is an accumulation of biofilm on a surface. To reduce these effects, other modes of biocide applications such as shock treatments and use of alternating biocides should to be considered.

\section{CONCLUDING REMARKS}

The RBC units were successfully used to simulate and predict the behaviour of a full-scale effluent treatment plant in the presence of an aldehyde biocide as well as the effect of the biocide on the activity and survival of the biofilms and planktonic cells. The biofilms became acclimated to glutaraldehyde and eventually degraded it. The degree of biocide degradation and COD removal depended on acclimation period, the presence of other organic matters and the amount of mineral salts available. No glutaraldehyde concentration used in the study was sufficiently high to eliminate microorganisms in the RBC system. Bacterial cells in biofilms were less susceptible to glutaraldehyde than their planktonic counterparts. The increased resistance of bacteria to glutaraldehyde due to acclimation should be considered in biocide applications.

\section{ACKNOWLEDGMENTS}

We would like to thank Ondeo Nalco, Thailand and Phoenix pulp and public company Ltd., Khon Kaen, Thailand for providing the commercial biocide and the inoculum respectively. We would like to thank Associate Prof. Dr. Sanha Panichajakul, Mahasarakham University, Thailand and Assistant Prof. Dr. Aroonwadee Chanawong, Khon Kaen University, Thailand for some instrumentation and chemical supports. We also would like to dedicate this paper to the memory of Dr. R.N. Smith. 


\section{REFERENCES}

APHA AWWA and WPCE. Standard Methods for the Examination of Water and Wastewater. $19^{\text {th }}$ ed. American Public Heath Association, Washington, DC, 1995. 1108 p. ISBN 0-87553-223-3.

APILÁNEZ, I.; GUTIERREZ, A. and DIAZ, M. Effect of surface materials on initial biofilm development. Bioresource Technology, December 1998, vol. 66, no. 3, p. 225-230.

ARUNDEL, J. Biological treatment methods. In: Sewage and Industrial Effluent Treatment. Cornwell, Blackwell Science Ltd, 1995, p. 71-105.

BAE, W. and RITTMANN, B.E. Accelerating the rate of cometabolic degradation requiring an intracellular electron source-model and biofilm application. Water Science and Technology, 1995, vol. 31, no. 1, p. 29-39.

BAILEY, H.C.; ELPHICK, J.R.; POTTER, A.; CHAO, E. and ZAK, B. Acute toxicity of the antisapstain chemicals DDAC and IPBC, alone and in combination, to rainbow trout (Oncorhynchus mykiss) Water Research, July 1999, vol. 33 , no. 10 , p. $2410-2414$.

BANERJEE, G. Treatment of phenolic wastewater in RBC reactor. Water Research, April 1997, vol. 31, no. 4, p. 705714.

BANNER, M.J. The selection of disinfectants for use in food hygiene. In: ROSSMOORE, H.W. ed. Handbook of Biocide and Preservative Use. Glasgow, Blackie Academic and Professional, 1995, p. 315-333.

BORATYNSKI, Janusz and ZAL, Tomasz. Colorimetric micromethods for glutaraldehyde determination by means of phenol and sulfuric acid or phenol and perchloric acid. Analytical Biochemistry, February 1990, vol. 184, no. 2, p. 259-262.

BOTT, T.R. Techniques for reducing the amount of biocide necessary to counteract the effects of biofilm growth in cooling water systems. Applied Thermal Engineering, November 1998, vol. 18, no. 11, p. 1059-1066.

BRÖZEL, V.S.; PIETERSEN, B. and CLOETE, T.E. Resistance of bacterial cultures to non-oxidising water treatment bactericides by adaptation. Water Science and Technology, 1995, vol. 31, no. 5-6, p. 169-175.

BRYERS, J.D. Biofilms: An introduction. In: Biofilms II: Process analysis and applications. New York, Wiley-Liss, 2000, p. 3-12.

CASEY, T.J. Aerobic biofilters. In: Unit Treatment Processes in Water and Wastewater Engineering. Chichester, Wiley, 1997, p. 177-188.
CHARACKLIS, W.G. and MARSHALL, K.C. Biofilms: A basis for an interdisciplinary approach. In: Biofilms. New York, John Wiley and Sons, 1990, p. 3-15.

CHEUNG, C.W.S. and BEECH, I.B. The use of biocides to control sulphate-reducing bacteria in biofilms on mild steel surfaces. Biofouling, 1996, vol. 9, no. 3, p. 231-249.

CHRISTENSEN, B.E. and CHARACKLIS, W.G. Physical and chemical properties of biofilm. In: Biofilms. New York, John Wiley and Sons, 1990, p. 93-130.

CLOETE, T.E.; JACOBS, L. and BRÖZEL, V.S. The chemical control of biofouling in industrial water systems. Biodegradation, January 1998, vol. 9, no. 1, p. 23-37.

CORNELISSEN, Gerald and SIJM, Dick T.H.M. An energy budget model for the biodegradation and cometabolism of organic substances. Chemosphere, September 1996, vol. 33, no. 5, p. 817-830.

DAS, J.R.; BHAKOO, M.; JONES, M.V. and GILBERT, P. Changes in the biocide susceptibility of Staphylococcus epidermidis and Escherichia coli cells associated with rapid attachment to plastic surfaces. Journal of Applied Microbiology, June 1998, vol. 84, no. 5, p. 852-858.

EGINTON, P.J.; HOLAH, J.; ALLISON, D.G.; HANDLEY, P.S. and GILBERT, P. Changes in the strength of attachment of micro-organisms to surfaces following treatment with disinfectants and cleansing agents. Letters in Applied Microbiology, August 1998, vol. 27, no. 2, p. 101-105.

FLEMMING, H.-C. Biofilms and environmental protection. Water Science and Technology, 1993, vol. 27, no. 7-8, p. 1-10.

HERBERT, B.N. Biocides in oilfield operations. In: ROSSMOORE, H.W. ed. Handbook of Biocide and Preservative Use. Glasgow, Blackie Academic and Professional, 1995, p. 185-206.

JOHNSTON, B.D.; SEUBERT, J.M. and KENNEDY, C.J. Biochemical effects of didecyldimethylammonium chloride (DDAC) exposure and osmoregulatory stress on juvenile coho salmon, Oncorhynchus kisutch. Archives of Environmental Contamination and Toxicology, April 1998, vol. 34 , no. 3, p. 275-279.

JUERGENSEN, Lars; BUSNARDA, Judy; CAUX, PierreYves and KENT, Robert A. Fate, behavior, and aquatic toxicity of the fungicide DDAC in the Canadian environment. Environmental Toxicology, June 2000, vol. 15 , no. 3 , p. $174-200$.

KERR, C.J.; OSBORN, K.S.; ROBSON, G.D. and HANDLEY, P.S. The relationship between pipe material and biofilm formation in a laboratory model system. 
Journal of Applied Microbiology Symposium Supplement, 1999 , vol. 85 , no. 28 , p. 29S-38S.

LAOPAIBOON, L.; SMITH, R.N. and HALL, S.J. A study of the effect of isothiazolones on the performance and characteristics of a laboratory-scale rotating biological contactor. Journal of Applied Microbiology, July 2001, vol. 91, no. 1, p. 93-103.

LAOPAIBOON, L.; HALL, S.J. and SMITH, R.N. The effect of a quaternary ammonium biocide on the performance and characteristics of laboratory-scale rotating biological contactors. Journal of Applied Microbiology, December 2002, vol. 93, no. 6, p. 1051-1058.

LAZAROVA, V. and MANEM, J. Innovative biofilm treatment technologies for water and wastewater treatment. In: BRYERS, J.D. ed. Biofilms II: Process analysis and applications. New York, Wiley-Liss, 2000, p. 159-206.

LUTEY, R.W. Process cooling water. In: ROSSMOORE, H.W. ed. Handbook of Biocide and Preservative Use. Glasgow, Blackie Academic and Professional, 1995, p. 5082.

MELO, L.F. and BOTT, T.R. Biofouling in water systems. Experimental Thermal and Fluid Science, May 1997, vol. 14 , no. 4 , p. $375-381$.

MORTON, L.H.G.; GREENWAY, D.L.A.; GAYLARDE, C.C. and SURMAN, S.B. Consideration of some implications of the resistance of biofilms to biocides. International Biodeterioration and Biodegradation, 1998, vol. 41, no. 3-4, p. 247-259.

NIKAIDO, Hiroshi. Prevention of drug access to bacterial targets: permeability barriers and active efflux. Science, April 1994, vol. 264, no. 5157, p. 382-388.

NISHIHARA, T.; OKAMOTO, T. and NISHIYAMA, N. Biodegradation of didecyldimethylammonium chloride by Pseudomonas fluorescens TN4 isolated from activated sludge. Journal of Applied Microbiology, April 2000, vol. 88 , no. 4, p. 641-647.

NISHIYAMA, Naohiro; TOSHIMA, Yasuhiko and IKEDA, Yuzu. Biodegradation of alkyltrimethylammonium salts in activated sludge. Chemosphere, February 1995, vol. 30, no. 3, p. 593-603.

NORWOOD, D.E. and GILMOUR, A. The growth and resistance to sodium hypochlorite of Listeria monocytogenes in a steady-state multispecies biofilm. Journal of Applied Microbiology, March 2000, vol. 88, no. 3, p. 512-520.

PHUKOETPHIM, N.; LAOPAIBOON, P.; VICHITPHAN, K. and LAOPAIBOON, L. Effect of an aldehyde biocide used in paper and pulp industry on a laboratory-scale wastewater treatment plant. In: The $16^{\text {th }}$ Annual Meeting of the Thai Society for Biotechnology. $\left(12^{\text {th }}-15^{\text {th }}\right.$ December, 2004, Pitsanulok, Thailand). 2004. p. 240-245.

REUTER, G. Disinfection and hygiene in the field of food of animal origin. International Biodeterioration and Biodegradation, 1998, vol. 41, no. 3-4, p. 209-215.

RUSSELL, A.D. and CHOPRA, I. Antiseptics, disinfectants, and preservatives: their properties, mechanisms of action and uptake into bacteria. In: Understanding Antibacterial Action and Resistance, $2^{\text {nd }}$ ed. Hertfordshire, Ellis Horwood, 1996, p. 96-149.

RUSSELL, A.D. Bacterial resistance to disinfectants: present knowledge and future problems. Journal of Hospital Infection, December 1998, vol. 43, Supplement 1, p. S57-S68.

SARLIN, T.; HALTTUNEN, S.; VUORIRANT, P. and PUHAKKA, J. Effects of chemical spills on activated sludge treatment performance in pulp and paper mills. Water Science and Technology, 1999, vol. 40, no. 11-12, p. 319-326.

SELVARAJU, Suresh B.; KHAN, Izhar U.H. and YADAV, Jagjit S. Biocidal activity of formaldehyde and nonformaldehyde biocides toward Mycobacterium immunogenum and Pseudomonas fluorescens in pure and mixed suspensions in synthetic metalworking fluid and saline. Applied and Environmental Microbiology, January 2005, vol. 71, no. 1, p. 542-546.

SIMONS, C.; WALSH, S.E.; MAILLARD, J.-Y. and RUSSELL, A.D. A note: Ortho-Phthalaldehyde: proposed mechanism of action of a new antimicrobial agent. Letters in Applied Microbiology, October 2000, vol. 31, no. 4, p. 299-302.

SOFER, S.S.; LEWANDOWSKI, G.A.; LODAYA, M.P.; LAKHWALA, F.S.; CHUNG YANG, K. and SINGH, M. Biodegradation of 2-chlorophenol using immobilized activated sludge. Research Journal of the Water Pollution Control Federation, 1990, vol. 62, no. 1, p. 73-80.

STEWART, P.S.; GRAB, L. and DIEMER, J.A. Analysis of biocide transport limitation in an artificial biofilm system. Journal of Applied Microbiology, September 1998, vol. 85, no. 3, p. 495-500.

STEWART, P.S.; MCFETERS, G.A. and HUANG, C.-T. Biofilm control by antimicrobial agents. In: BRYERS, J.D. ed. Biofilm II: Process analysis and applications. New York, Wiley-Liss, 2000, p. 373-405.

STOODLEY, P.; DODDS, I.; BOYLE, J.D. and LAPPINSCOTT, H.M. Influence of hydrodynamics and nutrients on biofilm structure. Journal of Applied Microbiology Symposium Supplement, 1999, vol. 85, no. 28, p. 19S-28S. 
TRULEAR, M.G. and CHARACKLIS, W.G. Dynamics of biofilm processes. Journal of the Water Pollution Control Federation, September 1982, vol. 54, no. 9, p. 1288-1301.

VAN GINKEL, C.G. Relations between the structure of quaternary alkyl ammonium salts and their biodegradability. Chemosphere, 1991, vol. 23, no. 3, p. 281-289.

VENKATARAMAN, R. and RAMANUJAM, T.K. A study on microbiology of biological film layer in rotating biological contactors. Bioprocess and Biosystems Engineering, March 1998, vol. 18, no. 3, p. 181-186.

WALSH, S.E.; MAILLARD, J.-Y. and RUSSELL, A.D. Ortho-phthalaldehyde: a possible alternative to glutaraldehyde for high level disinfection. Journal of Applied Microbiology, June 1999, vol. 86, no. 6, p. 10391046.

WYNDHAM, R.C. and KENNEDY, K.J. Microbial consortia in industrial wastewater treatment. In: LAPPINSCOTT, H.M. and COSTERTON, J.W. eds. Microbial Biofilms. Cambridge, Cambridge University Press, 1995, p. 183-195. 